$$
\begin{gathered}
\text { 경주 동궁과 월지의 생태적 수용력에 관한 연구 } \\
- \text { 탐방로의 이용행태 및 손상도를 중심으로 - } \\
\text { 이홍*·강태호** }
\end{gathered}
$$

*동국대학교 대학원 조경학과·*동국대학교 조경학과

\title{
A Study on the Ecological Carrying Capacity of Donggung and Wolji, Gyeongju - Centering around the Used Pattern and Damage Degree of Trail Routes -
}

\author{
$\mathrm{Li}$, Hong* ${ }^{*}$ Kang, Tai-Ho* \\ *Dept. of Landscape Architecture, Graduate School, Dongguk University \\ **Dept. of Landscape Architecture, Dongguk University
}

\begin{abstract}
In order to calculate the ecological carrying capacity of Donggung and Wolji, Gyeongju, the number and time for various activities of tourists were surveyed and then the injury tolerance on lawns was predicted with seven types of various activities. According to the injury tolerance in various activities for the suitable carrying capacity, the normal carrying capacity and the limited carrying capacity were explicitly determined in four lawns.

According to the number and time for various activities, the injury tolerance of various activities was predicted in four lawns, and the highest average injury tolerance was 2.15 in walking, the lowest average injury tolerance was 0.05 in lying. The highest injury tolerance was 1.31 in lawn 4, and then the order was 0.97 in lawn 3, 0.91 in lawn1, and 0.70 in lawn 2. The ecological carrying capacity was predicted with a damaged area according to the injury tolerance of various activities. The suitable carrying capacity was done separately to 40 persons, 249 persons, 107 persons, 37 persons, the limited carrying capacity was 116, 713, 306, 107 respectively and the normal carrying capacity was 75, 463, 198, 69 in four lawns. When managed in Donggung and Wolji, Gyeongju, the number of tourists was under the limited carrying capacity, the conformation would grow better.
\end{abstract}

Key Words: The Injury Tolerance, Damaged Area, Suitable Carrying Capacity, Limitative Carrying Capacity

$$
\text { 국문초록 }
$$

경주 동궁과 월지의 생태적 수용력 연구를 위해 유적지내에서 관찰되어지는 7 가지 이용행태에 따른 이용구간별 녹지 평균손상도를 산정하였다. 이를 위해 탐방객 이용행태의 이용인수 및 이용시간을 조사하고 손상도를 산정하였다. 각 이용행태별 손상도를 통하여 4가지 조사구의 적정수용력, 표준수용력과 한계수용력을 명확하게 파악할 수 있다.

Comesponding author: Tai-Ho Kang, Dept. of Landscape Architecture, Dongguk University, Gyeongju 780-714, Korea, Tel.: +8210-4508-2232, E-mail: kth@dongguk.ac.kr 
각 조사구의 이용행태별 이용인수 및 이용시간에 따른 손상도를 산정한 결과, '걷다'의 경우 평균 2.15 로 가장 높았고, '눕다'의 경우 0.05 로 가장 낮은 것으로 나타났다. 그리고 각 조사구의 손상도는 조사구 4가 1.31 로 가장 높았고, 조사구 3 이 0.97 , 조사구 1 이 0.91 , 조사구 2 가 0.70 의 순으로 나타났다. 각 조사구의 손상면적을 산정 후에 생태적 수용력을 추정한 결과, 조사구 $1,2,3,4$ 의 적정수용력은 각각 40 인, 249 인, 107 인, 37 인, 한계수용력은 각각 116 인, 713 인, 306 인, 107 인, 표준수용력은 각각 75 인, 463 인, 198 인, 69 인으로 추정된다. 경주 동궁과 월지의 바람직한 관리를 위한 최대의 생태적 수용력은 한계수용력 이하로 하는 것이 적합하다.

주제어: 손상도, 손상면적, 적정수용력, 한계수용력

\section{I. 서론}

\section{1. 연구의 배경과 목적}

경주 동궁과 월지는 신라가 삼국 통일을 이룬 직후인 문무왕 (文武王) 14년(674년)에 황룡사 서남쪽에 조성된 신라 천년의 궁성지이다. 경주 동궁과 월지는 일제강점기에 철도가 통과하 는 등 많은 훼손을 입었으나 발굴조사를 거쳐 임해전 터로 추 정되는 곳을 비롯하여 연못 주변 회랑지 및 크고 작은 건물터 26 곳을 확인하였다. 그 중에 신라 건물터로 보이는 3 곳과 월지 를 복원하여 세계 정원사에 있어 완전한 모습을 갖춘 가장 오 래된 유적으로 남아 있다.

최근에는 야경을 위한 조명 시설을 설치하여 주간만이 아니 라 야간에도 많은 관광객이 찾는 경주의 대표적인 유적지가 되 었다. 그러나 경주 동궁과 월지는 많은 관광객의 탐방으로 인 하여 수용력의 한계를 초과하고 있는 실정이다. 특히 야간 개 장 이후 수면에 비친 건물의 야경이 매우 아름다워 관광객이 일정한 시간대 집중으로 식생환경 손상과 유적지의 훼손이 초 래되고 있다.

따라서 경주 동궁과 월지가 적정수용력에 따라 통제되고 관 리되지 못한다면 물리적, 생태적 한계를 벗어나 세계유산 관리 에 있어 악영향을 초래할 것이다.

수용력에 관한 연구는 목축이나 도시생활에 관한 양적인 측 면이나 시설구비를 위해 시작되었으나, 최근에는 환경의 보호 와 관광 - 레크리에이션 시설의 개선을 위한 연구로 수행된다 (Canestrelli and Costa, 1991; 국립공원관리공단, 2007).

우리나라에서는 주로 국립공원에서의 야영장 및 피크닉장소 에서의 이용객에 의한 자연파괴 현황과 심리적 수용력에 관한 연구가 진행되어 왔으나, 외국에서는 자연공원에서 이용객이 자연생태계에 미치는 영향에 관한 연구와 이용객의 심리적 만 족도에 의한 수용력에 관한 연구로 진행되고 있다. 물리적인 측면과 더불어 사회적·심리적 측면을 고려한 수용력 연구의 발전은 우리가 당면한 문제를 해결하기 위한 유용한 방법론적 가능성을 제시하고 있다(박지나 등, 2009; 오규식 등, 2002; 김 선희, 2005; 김창수와 김의근, 1995 ; 신원섭 등, 2007). 그러나
국내에서는 공원이나 유원지를 비롯한 대부분의 행락지에서 과잉이용에 의해 자연자원의 파괴가 심화되어 가고 있음에도 불구하고, 이에 대처할 수 있는 연구는 아직 미흡한 상태이다.

특히 경주 동궁과 월지와 같은 유적지에 대한 연구는 주로 유적정비나 경관관리 등과 관련된 연구가 이루어졌고, 생태적 수용력에 대한 연구는 없다.

이 연구는 우리나라의 중요한 유적지 중에 하나인 경주 동궁 과 월지를 대상으로 생태적 수용력을 연구하여 보다 나은 유적 지 관리를 할 수 있도록 각 활동별 탐방인원을 파악, 분석하여 적정한 수용력을 알아보는데 목적이 있다.

경주 동궁과 월지 탐방객의 이용행태별 이용인수, 이용시간 및 이용빈도를 조사 분석하여 탐방객들의 적정수용력, 표준수 용력과 한계수용력을 파악하고자 한다.

\section{2. 연구의 범위}

이 연구 수행을 위한 공간적 범위는 경주 동궁과 월지의 4 가 지 조사구 내에 한정하여 실시한다. 조사구를 4 구역으로 구분 한 이유와 기준은 조사구1(대조구)은 건축물 유적지 공간으로 잔디밭으로만 조성되었고 나머지 2, 3, 4는 숲과 잔디밭으로 구 성되어 탐방객들이 이용하고 있는 지역이다. 다른 지역은 탐방 객들이 진입금지 구역이다. 연구 대상에 포함되는 유적의 명칭 은 발굴 후 측량도에 명기된 표기에 따른다.

내용적 범위는 경주 동궁과 월지의 탐방객의 이용인수와 이 용시간을 대상으로 현장 관측을 실시하여 분석한다.

\section{3. 이론적 고찰}

적정수용력은 일반적으로 현저한 질적 저하나 파괴 없이 인 구성장이나 물리적 개발을 수용할 수 있는 자연 또는 인공 환 경의 능력을 의미한다. 즉 수용력은 자연환경이 지탱할 수 있 는 성장과 개발의 양은 내재적인 한계, 즉 임계영역이 있고, 그 임계영역은 규명될 수 있으며, 외적 조건의 조작을 통해 증감시 킬 수 있다는 가정 하에 성립한다(Godschalk and Parker, 1975). 생태적 수용력(Ecological Carrying Capacity)은 자기회복능 
력이나 자기정화능력의 한계 내에서 자연생태계의 본질적인 메카니즘이 교란, 파괴되지 않는 범위에서 인간 활동을 흡수, 지탱하고 스스로 회복할 수 있는 능력을 의미하는 것으로 최대 인간 활동 강도 또는 밀도를 뜻한다. 이는 자연 및 생태적 자원 성에 기초한 개념으로 동식물의 비율, 개체수, 토양침식 및 토 양답압 정도 등 자연요소의 내성이 지표가 된다.

생태적 수용력에 대한 연구는 조현길(1989)은 지리산국립공 원 화엄사지구를 대상으로 하여 자원의 지력 저하를 막는 동시 에 탐방객 경험의 질을 유지하기 위한 적정수용력을 추정하였 는데, 생태적 수용력의 경우 $100 \mathrm{~m}^{2}$ 인으로 추정하였다.

\section{II. 재료 및 방법}

\section{1. 조사대상지}

경주 동궁과 월지는 총면적이 $7 \mathrm{D}_{\mathrm{L}}^{2}$ 이고 신라 천년의 궁궐 인 월성의 북동쪽에 인접하고 있다. 《삼국사기》 문무왕 14 년 $(\mathrm{AD} 674)$ 조(條)를 보면 궁성 안에 못을 파고 산을 만들어 화 초를 심고 진금이수(珍禽異獸)를 양육하였다고 하였는데, 동궁 과 월지는 바로 그때 판 못이며 서쪽에 위치한 신라 왕궁의 별궁 이다. 동궁과 월지는 사적 제18호로 지정되었으며, 2000 년에 유 적의 가치를 인정받아 세계유산으로 등재되었다(그림 1 참조).

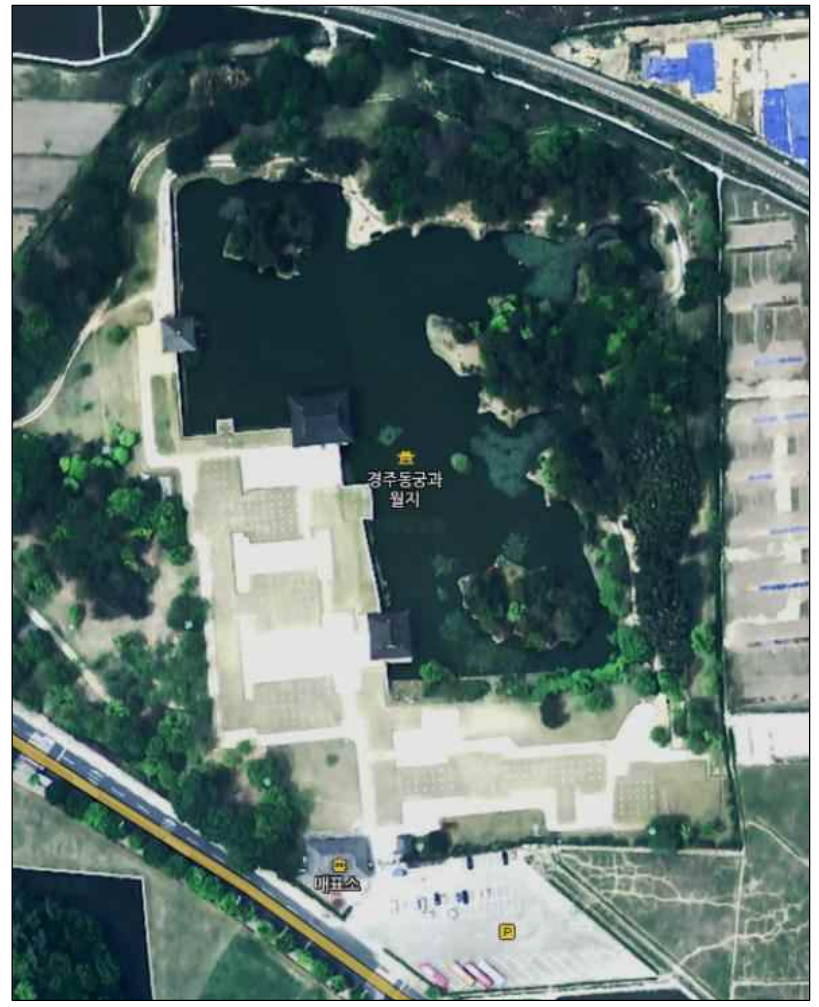

그림 1. 경주 동궁과 월지 위성사진

자료: http://map.naver.com

\section{2. 조사방법}

경주 동궁과 월지 탐방객의 생태적 수용력을 추정하기 위하 여 조사대상지를 4구역으로 구분하였다(그림 2 참조). 4가지 조사구의 잔디구성은 우리나라 공원잔디의 대부분을 차지하고 있는 잔디(Zoysia japonica)이며(그림 3 참조), 식재 면은 조사 구 1: 2,300 $\mathrm{m}^{2}$, 조사구 2: $15,000 \mathrm{~m}^{2}$, 조사구 3: $6,100 \mathrm{~m}^{2}$, 조사구 4: $7,500 \mathrm{~m}^{2}$ 이다 $(\mathrm{CAD}$ 를 통하여 산출). 조사구 1 은 건축물의 유 적지로 보여 지는 공간으로 잔디밭으로만 조성되었고 나머지 $2,3,4$ 는 숲과 잔디밭으로 구성되어 관람 시 휴식 등 다양한

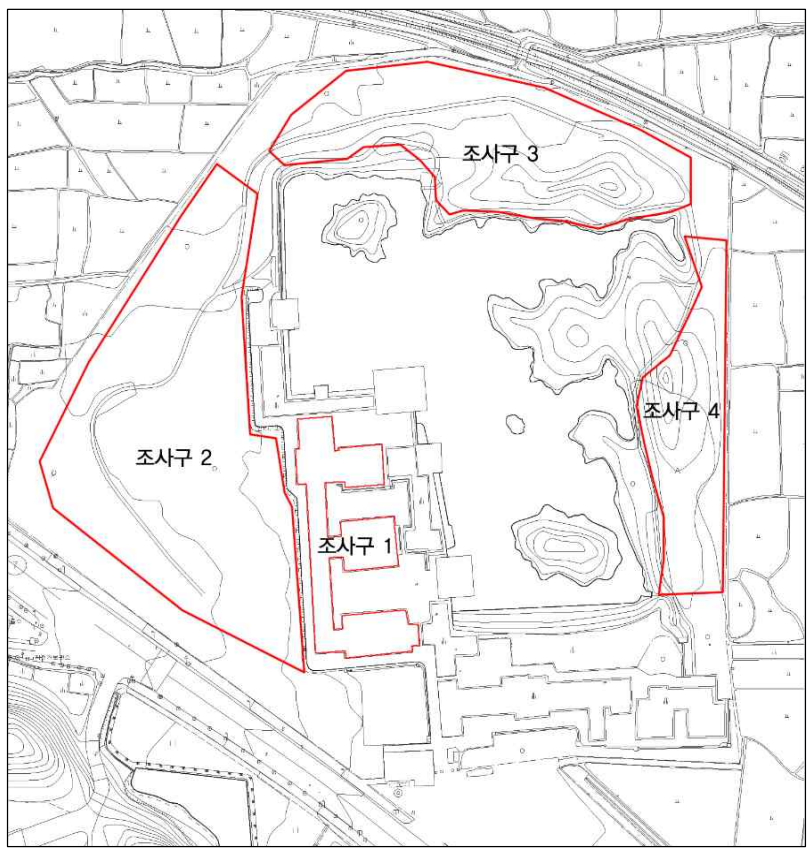

그림 2. 조사구 범위

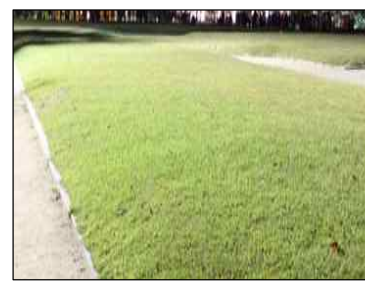

a: 조사구 1

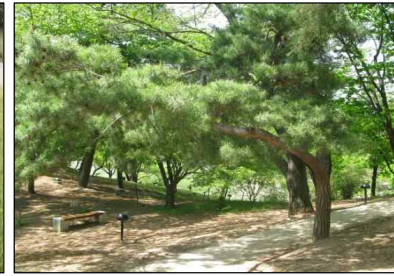

$\mathrm{b}$ : 조사구 2
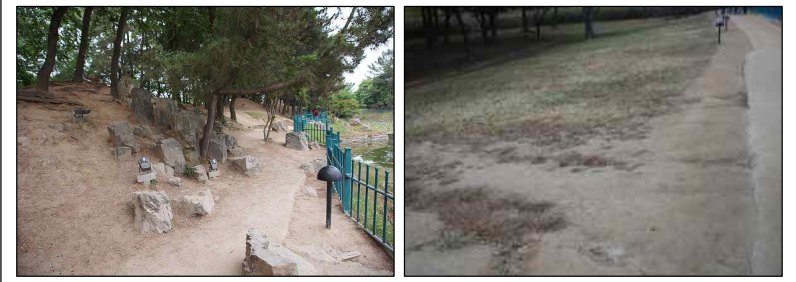

c: 조사구 3

d: 조사구 4

그림 3. 조사구 현황사진 
행위가 있지만 그 평가기준은 동일하게 적용하였다. 그 이유는 조사구 1은 대조구이며 $2,3,4$ 는 잔디밭만의 손상도를 계산하

\section{표 1. 이용행태별 평균 이용인수와 평균 이용시간}

\begin{tabular}{|c|c|c|c|}
\hline & 이용행태 & 평균 이용인수 & 평균 이용시간(분) \\
\hline \multirow{7}{*}{$\begin{array}{c}\text { 조사구 } \\
1\end{array}$} & Run(뛰다) & 6 & 0.5 \\
\hline & Walk(걷다) & 21 & 1 \\
\hline & Spring/Jump(뛰어오르다) & 3 & 0.5 \\
\hline & Stop(멈추다) & 10 & 2 \\
\hline & Stand up(일어서다) & 15 & 2 \\
\hline & Sit down(앉다) & 19 & 15 \\
\hline & Lie down(눕다) & 5 & 2 \\
\hline \multirow{7}{*}{$\begin{array}{c}\text { 조사구 } \\
2\end{array}$} & $\operatorname{Run(ㄸㅟㄷㅏ)~}$ & 2 & 2 \\
\hline & Walk(걷다) & 22 & 5 \\
\hline & Spring/Jump(뛰어오르다) & 0 & 0 \\
\hline & Stop (멈추다) & 5 & 1 \\
\hline & Stand up(일어서다) & 32 & 5 \\
\hline & Sit down(앉다) & 11 & 10 \\
\hline & Lie down(눕다) & 0 & 0 \\
\hline \multirow{7}{*}{$\begin{array}{c}\text { 조사구 } \\
3\end{array}$} & Run(뛰다) & 6 & 1 \\
\hline & Walk(걷다) & 25 & 3 \\
\hline & Spring/Jump(뛰어오르다) & 12 & 1 \\
\hline & Stop(멈추다) & 8 & 2 \\
\hline & Stand up(일어서다) & 11 & 1 \\
\hline & Sit down(앉다) & 24 & 8 \\
\hline & Lie down(눕다) & 0 & 0 \\
\hline \multirow{7}{*}{$\begin{array}{c}\text { 조사구 } \\
4\end{array}$} & $\operatorname{Run(ㄸㅟㄷㅏ)~}$ & 10 & 2 \\
\hline & Walk(걷다) & 56 & 10 \\
\hline & Spring/Jump(뛰어오르다) & 8 & 2 \\
\hline & Stop(멈추다) & 12 & 5 \\
\hline & Stand up(일어서다) & 13 & 2 \\
\hline & Sit down(앉다) & 8 & 10 \\
\hline & Lie down(눕다) & 0 & 0 \\
\hline
\end{tabular}

여 생태적 수용력을 파악하였기 때문에 숲과는 관계가 없다. 또한, 다양한 행위를 포함하여 손상도를 계산하였기 때문에 평 가기준이 동일하다고 보았다.

탐방객 이용행태 및 이용시간은 관광 성수기(벛꽃이 매우 아름다워 탐방객이 가장 많은 시기)인 2012년 4월 10일부터 4 월 20일까지 11:00시, 15:00시, 20:00시 매일 3회씩 매회 30분 간 실시하였고 이용행태별 각 조사구의 평균 이용인수와 평균 이용시간을 조사하였다(표 1 참조). 각 조사구별로 2 3인의 조사원을 배치하여 할당된 잔디공간내의 이용자 이용행태별 및 이용인수를 관찰조사 기록용지에 매30분 단위로 기입하게 하였다. 한 명이 다양한 활동을 할 경우는 각 이용행태에 따라 중복하여 기록하였다. 그 이유는 단 한 명이라 할지라도 각 활 동별 손상도가 크기 때문이다.

잔디공간에서 이루어지는 이용행태는 매우 다양한데, 이러 한 다양한 이용행태들을 7 가지의 유형으로 구분하였다. '일어 서다'는 조사구에 따라 다른 이유가 '일어서다'는 '서다'를 포함 하고 있기 때문에 조사구에 따라 시간이 다르다. 예를 들면 사 진을 찍을 때 조사구에 따른 서는 시간이 다른 것으로 조사되었 다. 조사한 데이터는 통계분석 프로그램 SPSS 18.0(IBM SPSS, 2009)을 사용하여 분석하였다.

\section{3. 이용행태별 손상면적의 계산}

각각 이용행태별로 평균이용시간과 분당 활동량(예: 활동횟 수×평균접촉 면적) 및 녹지손상도('걷다'의 손상도를 기준으로 함) 등을 근거로 손상면적을 산출하였다(표 2 참조).

각 이용행태별로 분당 활동량은 近藤三雄(1980)의 추정치를 인용하여 적용하였다. 손상면적 산출에 있어 걷는 활동을 제외 한 활동들의 경우에는, 이들 각 활동에 따른 잔디손상도를 기 본활동인 '걷다'의 손상도 2.9 로 환산한 값으로 산출하였다. 또한 1 분당 평균거리 및 평균횟수의 추정치로 보면 '뛰다’가

표 2. 손상면적 계산방법

\begin{tabular}{|c|c|c|c|c|}
\hline 조사구 & 이용행태 & 손상면적 계산 & 1인 평균 손상면적 & 손상면적 \\
\hline \multirow{11}{*}{$\begin{array}{c}\text { 조사구 } \\
1\end{array}$} & \multirow{2}{*}{ Walk(걷다) } & 평균이용시간×분당 평균거리보폭×평균 발면적 & & \\
\hline & & $(1$ 분 $) \times(60 \mathrm{~m}) \div(0.55 \mathrm{~m}) \times\left(0.016 \mathrm{~m}^{2}\right)$ & 1.75 & 36.65 \\
\hline & \multirow{2}{*}{ Run(뛰다) } & 평균이용시간×분당 평균거리 $\div$ 보폭×평균 접촉 면적×(손상도/보행 손상도) & & \\
\hline & & $(0.5$ 분 $) \times(160 \mathrm{~m}) \div(0.8 \mathrm{~m}) \times\left(0.016 \mathrm{~m}^{2}\right) \times(3.3 / 2.9)$ & 1.82 & 10.92 \\
\hline & & 평균이용시간×분당 평균횟수×평균 접촉 면적×(손상도/보행 손상도) & & \\
\hline & Spring/Jump(뛰어오르다) & $(0.5$ 분 $) \times(50$ 회 $) \times\left(0.032 \mathrm{~m}^{2}\right) \times(3.3 / 2.9)$ & 0.91 & 2.73 \\
\hline & Stop(멈추다) & $(2$ 분 $) \times(35$ 회 $) \times\left(0.032 \mathrm{~m}^{2}\right) \times(10 / 2.9)$ & 7.72 & 77.24 \\
\hline & Stand up(일어서다) & $(2$ 분 $) \times(30$ 회 $) \times\left(0.032 \mathrm{~m}^{2}\right) \times(2 / 2.9)$ & 1.32 & 19.86 \\
\hline & Sit down(앉다) & $(15$ 분 $) \times(30$ 회 $) \times\left(0.039 \mathrm{~m}^{2}\right) \times(2 / 2.9)$ & 12.10 & 229.97 \\
\hline & Lie down(눕다) & $(2$ 분 $) \times(15$ 회 $) \times\left(0.18 \mathrm{~m}^{2}\right) \times(2 / 2.9)$ & 3.72 & 18.62 \\
\hline & 합계 & & 29.35 & 396.00 \\
\hline
\end{tabular}


(표 2. 계속)

\begin{tabular}{|c|c|c|c|c|}
\hline \multirow{11}{*}{$\begin{array}{c}\text { 조사구 } \\
2\end{array}$} & \multirow{2}{*}{ Walk(걷다) } & 평균이용시간×분당 평균거리보폭×평균 발면적 & & \\
\hline & & $(5$ 분 $) \times(60 \mathrm{~m}) \div(0.55 \mathrm{~m}) \times\left(0.016 \mathrm{~m}^{2}\right)$ & 8.73 & 192.00 \\
\hline & \multirow{2}{*}{$\operatorname{Run}$ (뛰다) } & 평균이용시간×분당 평균거리 보폭×평균 접촉 면적×(손상도/보행 손상도) & & \\
\hline & & $(2$ 분 $) \times(160 \mathrm{~m}) \div(0.8 \mathrm{~m}) \times\left(0.016 \mathrm{~m}^{2}\right) \times(3.3 / 2.9)$ & 7.28 & 14.57 \\
\hline & & 평균이용시간×분당 평균횟수×평균 접촉 면적×(손상도/보행 손상도) & & \\
\hline & Spring/Jump(뛰어오르다) & $(0$ 분 $) \times(50$ 회 $) \times\left(0.032 \mathrm{~m}^{2}\right) \times(3.3 / 2.9)$ & 0.00 & 0.00 \\
\hline & Stop(멈추다) & $(1$ 분 $) \times(35$ 회 $) \times\left(0.032 \mathrm{~m}^{2}\right) \times(10 / 2.9)$ & 3.86 & 19.31 \\
\hline & Stand up(일어서다) & $(5$ 분 $) \times(30$ 회 $) \times\left(0.032 \mathrm{~m}^{2}\right) \times(2 / 2.9)$ & 3.31 & 105.93 \\
\hline & Sit down(앉다) & $(10$ 분 $) \times(30$ 회 $) \times\left(0.039 \mathrm{~m}^{2}\right) \times(2 / 2.9)$ & 8.07 & 88.76 \\
\hline & Lie down(눕다) & $(0$ 분 $) \times(15$ 회 $) \times\left(0.18 \mathrm{~m}^{2}\right) \times(2 / 2.9)$ & 0.00 & 0.00 \\
\hline & 합계 & & 31.25 & 420.57 \\
\hline \multirow{11}{*}{$\begin{array}{c}\text { 조사구 } \\
3\end{array}$} & \multirow{2}{*}{ Walk(걷다) } & 평균이용시간×분당 평균거리보폭×평균 발면적 & & \\
\hline & & $(3$ 분 $) \times(60 \mathrm{~m}) \div(0.55 \mathrm{~m}) \times\left(0.016 \mathrm{~m}^{2}\right)$ & 5.24 & 130.91 \\
\hline & \multirow{2}{*}{$\operatorname{Run}$ (뛰다) } & 평균이용시간×분당 평균거리 $\div$ 보폭×평균 접촉 면적×(손상도/보행 손상도) & & \\
\hline & & $(1$ 분 $) \times(160 \mathrm{~m}) \div(0.8 \mathrm{~m}) \times\left(0.016 \mathrm{~m}^{2}\right) \times(3.3 / 2.9)$ & 3.64 & 21.85 \\
\hline & & 평균이용시간×분당 평균횟수×평균 접촉 면적×(손상도/보행 손상도) & & \\
\hline & Spring/Jump(뛰어오르다) & $(1$ 분 $) \times(50$ 회 $) \times\left(0.032 \mathrm{~m}^{2}\right) \times(3.3 / 2.9)$ & 1.82 & 21.85 \\
\hline & Stop(멈추다) & $(2$ 분 $) \times(35$ 회 $) \times\left(0.032 \mathrm{~m}^{2}\right) \times(10 / 2.9)$ & 7.72 & 61.79 \\
\hline & Stand up(일어서다) & $(1$ 분 $) \times(30$ 회 $) \times\left(0.032 \mathrm{~m}^{2}\right) \times(2 / 2.9)$ & 0.66 & 7.28 \\
\hline & Sit down(앉다) & $(8$ 분 $) \times(30$ 회 $) \times\left(0.039 \mathrm{~m}^{2}\right) \times(2 / 2.9)$ & 6.46 & 154.92 \\
\hline & Lie down(눕다) & $(0$ 분 $) \times(15$ 회 $) \times\left(0.18 \mathrm{~m}^{2}\right) \times(2 / 2.9)$ & 0.00 & 0.00 \\
\hline & 합계 & & 25.54 & 398.61 \\
\hline \multirow{11}{*}{$\begin{array}{c}\text { 조사구 } \\
4\end{array}$} & \multirow{2}{*}{ Walk(걷다) } & 평균이용시간×분당 평균거리보폭×평균 발면적 & & \\
\hline & & $(10$ 분 $) \times(60 \mathrm{~m}) \div(0.55 \mathrm{~m}) \times\left(0.016 \mathrm{~m}^{2}\right)$ & 17.45 & 977.45 \\
\hline & \multirow{2}{*}{$\operatorname{Run}$ (뛰다) } & 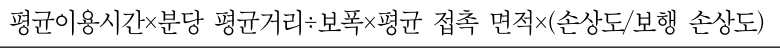 & & \\
\hline & & $(2$ 분 $) \times(160 \mathrm{~m}) \div(0.8 \mathrm{~m}) \times\left(0.016 \mathrm{~m}^{2}\right) \times(3.3 / 2.9)$ & 7.28 & 72.83 \\
\hline & & 평균이용시간×분당 평균횟수×평균 접촉 면적×(손상도/보행 손상도) & & \\
\hline & Spring/Jump(뛰어오르다) & $(2$ 분 $) \times(50$ 회 $) \times\left(0.032 \mathrm{~m}^{2}\right) \times(3.3 / 2.9)$ & 3.64 & 29.13 \\
\hline & Stop(멈추다) & $(5$ 분 $) \times(35$ 회 $) \times\left(0.032 \mathrm{~m}^{2}\right) \times(10 / 2.9)$ & 19.31 & 231.72 \\
\hline & Stand up(일어서다) & $(2$ 분 $) \times(30$ 회 $) \times\left(0.032 \mathrm{~m}^{2}\right) \times(2 / 2.9)$ & 1.32 & 17.21 \\
\hline & Sit down(앉다) & $(10$ 분 $) \times(30$ 회 $) \times\left(0.039 \mathrm{~m}^{2}\right) \times(2 / 2.9)$ & 8.07 & 64.55 \\
\hline & Lie down(눕다) & $(0$ 분 $) \times(15$ 회 $) \times\left(0.18 \mathrm{~m}^{2}\right) \times(2 / 2.9)$ & 0.00 & 0.00 \\
\hline & 합계 & & 57.08 & $1,392.90$ \\
\hline
\end{tabular}

$160 \mathrm{~m} /$ 분, '걷다'가 $60 \mathrm{~m} /$ 분 등의 거리로 나타나고, '뛰어오르다' 가 50회/분, '멈추다'가 35회/분, '눕다'가 15회/분 및 '일어서 다', '앉다' 등이 각 30 회/분 등의 횟수로 추정되었다.

\section{4. 생태적 수용력의 계산}

위에서 계산된 총 손상면적을 실험에서 설정된 바 있는 녹지 공간의 수용력을 이용횟수 기준으로 환산하여 생태적 수용력 으로 추정하고, 이를 다시 단위 면적 $\left(\mathrm{m}^{2}\right)$ 당 이용인수로 환산하 여 각 녹지공간에 적용하여 고찰하였다.
산출공식은 다음과 같다.

적정수용력=녹지총면적/(손상면적/7) 식 1 표준수용력=녹지총면적/(손상면적/13) 식 2 한계수용력=녹지총면적/(손상면적/20)

엄붕훈(1992)의 생태적 수용력의 측정 결과에 따라서 엽편 의 수량, 직립경수의 감소와 시각의 평가값의 감소 등을 기준 으로 손상횟수/일을 지표로 한 수용능력의 기준을 추정한 결 과, 적정수용력은 7회/일, 표준수용력은 13회/일, 한계수용력은 
20회/일로 추정하였다.

\section{III. 결과 및 고찰}

\section{1. 조사구의 이용행태 비율 및 시간}

1) 이용행태

각 조사구별 이용행태 비율은 그림 4 와 같으며 조사결과 유 의적인 차이가 있는 것으로 나타났다(표 3 참조).

조사구 1 에서의 이용행태 비율은 '걷다', '멈추다', '일어서다', '앉다'의 비율은 각각 $26.58 \%, 12.66 \%, 18.99 \%, 24.05 \%$ 로 나타 났다. 특히 '뛰어오르다'보다 '걷다'의 비율이 7배 정도 많은 것 으로 나타났다. 조사구 2에서는 '걷다', '일어서다', '앉다'의 비 율이 각각 $30.56 \%, 44.44 \%, 15.28 \%$ 로 나타났다. 조사구 3 에서는 '걷다', '뛰어오르다', '일어서다', '앉다'의 비율이 각각 $29.07 \%$, $13.95 \%, 12.79 \%, 27.91 \%$ 로 나타났다. 조사구 4에서는 '걷다', '멈추다', '일어서다'의 비율이 각각 $52.34 \%, 11.21 \%, 12.15 \%$ 로 나타났다.

조사구 $1,3,4$ 에서는 '걷다'의 비율이 가장 높았고, 조사구 2 에서는 '일어서다'의 비율이 가장 높게 나타났으며 조사구 2, 3,

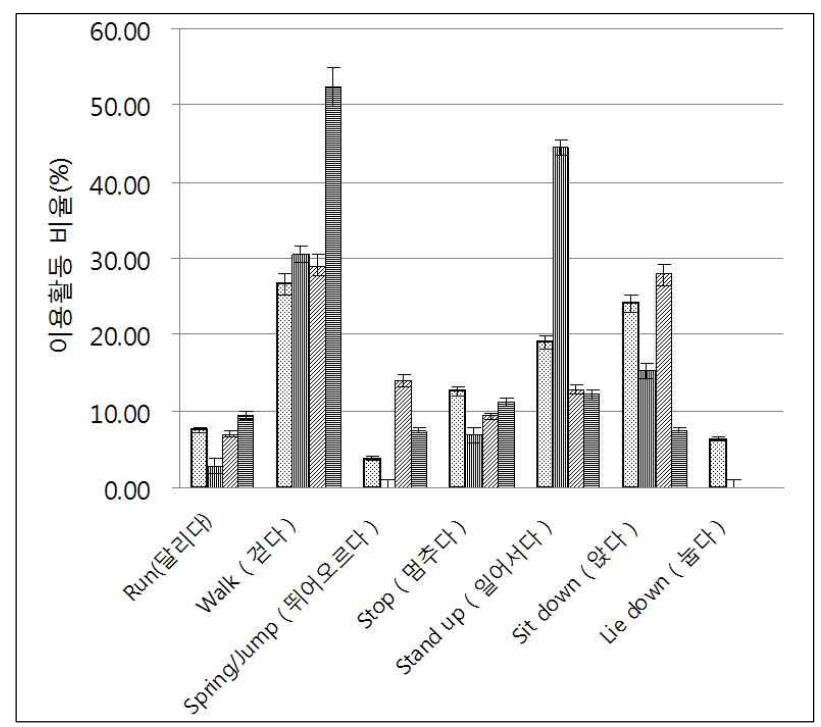

그림 4. 각 이용행태의 비율

범례: 미조사구 1, 四 조사구 2, 짖 조사구 3, 밀 조사구 4

표 3. 조사구에 따른 최대 및 최소 이용행태

\begin{tabular}{c|c|c||c|c}
\hline 조사구별 & 최대 이용행태 & 비율(\%) & 최소 이용행태 & 비율(\%) \\
\hline 조사구 1 & 걷다 & 26.58 & 뛰어오르다 & 3.80 \\
\hline 조사구 2 & 일어서다 & 44.44 & 뛰어오르다, 눕다 & 0 \\
\hline 조사구 3 & 걷다 & 29.07 & 눕다 & 0 \\
\hline 조사구 4 & 걷다 & 52.34 & 눕다 & 0 \\
\hline
\end{tabular}

4에서 '눕다'는 나타나지 않았다.

\section{2) 이용행태시간}

조사구 $1,2,3,4$ 에서는 '앉다'가 차지하는 시간이 가장 많았 고 조사구 4 에서는 '걷다'의 시간이 가장 많았다(표 4, 그림 5 참조). 조사구 4는 도로 옆에 있으며 통과 도로의 폭이 너무 좁 아서 '걷다'의 시간이 많은 것으로 판단된다.

\section{2. 이용행태별 손상도}

1) 이용행태별 손상도 분석 기준

\section{표 4. 조사구별 이용행태 비율}

\begin{tabular}{c|c|c||c|c}
\hline 조사구별 & 최대시간 & 비율(\%) & 최소시간 & 비율(\%) \\
\hline 조사구 1 & 앉다 & 65.22 & 뛰어오르다, 달리다 & 2.17 \\
\hline 조사구 2 & 앉다 & 43.48 & 뛰어오르다, 눕다 & 0 \\
\hline 조사구 3 & 앉다 & 50.00 & 눕다 & 0 \\
\hline 조사구 4 & 걷다, 앉다 & 32.26 & 눕다 & 0 \\
\hline
\end{tabular}

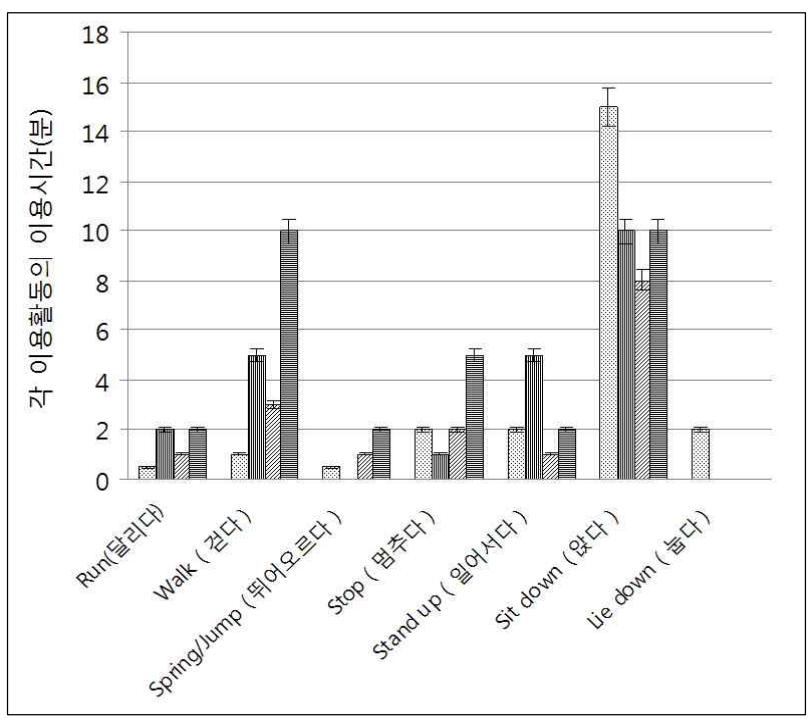

그림 5. 이용행태별 이용시간

범례: 미노사구 1 , 四 조사구 2, 圂 조사구 3 , 밀 조사구 4

표 5. 이용행태별 손상도

\begin{tabular}{c|c}
\hline 이용행태 & 손상도 \\
\hline 달리다 & 3.3 \\
\hline 걷다 & 2.9 \\
\hline 뛰어오르다 & 3.3 \\
\hline 멈추다 & 10.0 \\
\hline 일어서다 & 2.0 \\
\hline 앉다 & 2.0 \\
\hline 눕다 & 2.0 \\
\hline
\end{tabular}


近藤三雄(1980)가 설정한 바 있는 12 가지 이용행태에 따른 잔디 손상도 자료를 활용하였다. 近藤는 각 이용행태별로 운동 화와 가죽구두, 발바닥 전체와 발끝 등의 방식으로 각 1,000 회 씩 금잔디에서 행한 뒤, 이들로 인한 녹지손상도를 평균값으로 구한 것이다(표 5 참조). 엄붕훈(1992)의 연구결과 잔디와 금 잔디의 차이가 없는 것으로 나타났다.

녹지손상도는 '멈추다'의 손상도가 10.0으로 가장 높았고, 다 른 이용행태들은 2.0 3.3 정도로 낮은 편이다(엄붕훈, 1992).

\section{2) 이용행태별 녹지손상도}

그림 6 에서 보는 바와 같이 이용행태에 따른 차이는 손상도 의 경우 유의성이 인정되었다. 손상도는 이용행태에 따른 '걷 다'의 경우 평균 2.15 로 가장 높았고 '눕다'의 경우 0.05 로 가장 낮은 것으로 나타났다.

각 조사구의 평균손상도 분산분석 결과 유의적인 차이가 있 는 것으로 나타났다( $\mathrm{P}=0.001)$ (표 6 참조). 그리고 각 이용행 태별 평균 손상도에 있어서도 차이가 있는 것으로 나타났다. 각각의 이용행태별 녹지의 평균손상도는 '걷다' 2.15 >'멈추다' 2.10 >'일어서다' 0.825 >'앉다' 0.75 >'달리다' 0.5 >'뛰어오르다' 0.45 >'눕다' 0.05 의 순이다(표 7 참조).

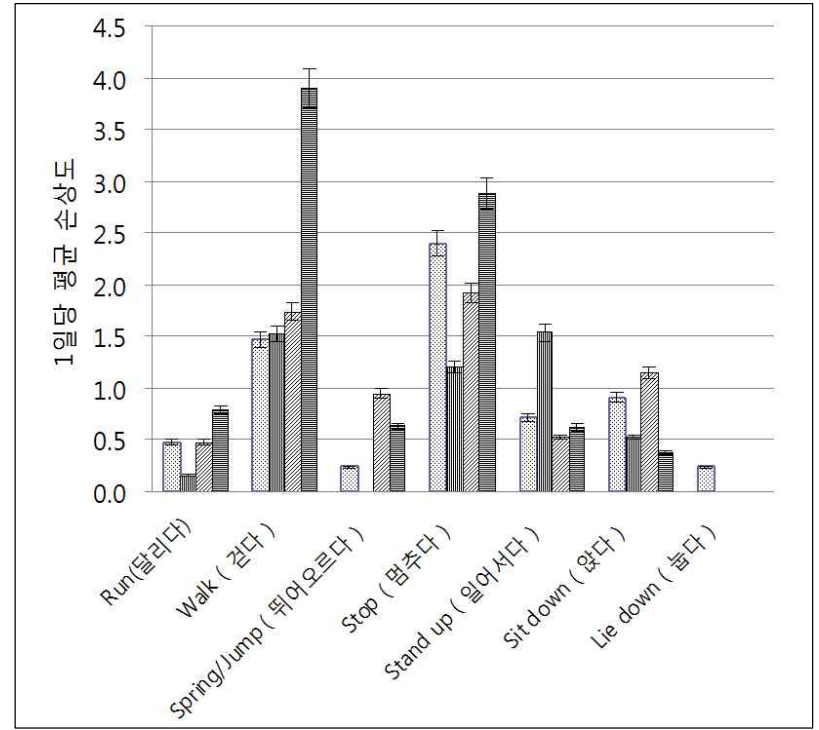

그림 6. 1일 평균 손상도

범례: 미 조사구 1 , 四 조사구 2 , 圂 조사구 3 , 믈 조사구 4

표 6. 각 조사구별 평균 손상도

\begin{tabular}{c|c|c|c}
\hline 조사구 & 평균 손상도 & 표준편차 & 유의확률 \\
\hline 조사구 1 & 0.91 & 0.01 & \multirow{2}{*}{$0.001 *$} \\
\cline { 1 - 3 } 조사구 2 & 0.70 & 0.02 & \\
\hline 조사구 3 & 0.97 & 0.02 & \\
\cline { 1 - 3 } 조사구 4 & 1.31 & 0.04 & \\
\hline $\mathrm{p} \leq 0.001 *$ & &
\end{tabular}

표 7. 각 이용행태별 평균 손상도

\begin{tabular}{c|c|c}
\hline 이용행태 & 평균 손상도 & 표준편차 \\
\hline Walk(걷다) & 2.15 & 0.03 \\
\hline Run(뛰다) & 0.50 & 0.02 \\
\hline Spring/Jump(뛰어오르다) & 0.45 & 0.01 \\
\hline Stop(멈추다) & 2.10 & 0.02 \\
\hline Stand up(일어서다) & 0.83 & 0.01 \\
\hline Sit down(앉다) & 0.75 & 0.03 \\
\hline Lie down(눕다) & 0.05 & 0.02 \\
\hline
\end{tabular}

표 8. 1일 평균 손상면적

\begin{tabular}{c|c|c}
\hline 조사구 & 1일 평균 손상면적 $\left(\mathrm{m}^{2}\right)$ & 표준편차 \\
\hline 조사구 1 & 396.00 & 27.32 \\
\hline 조사구 2 & 420.57 & 25.46 \\
\hline 조사구 3 & 398.61 & 35.44 \\
\hline 조사구 4 & $1,392.90$ & 23.59 \\
\hline
\end{tabular}

조사 결과 '걷다'와 '멈추다' 는 다른 이용행태와의 차이가 아 주 높지만 $(\mathrm{P}=0.001)$ '일어서다'와 '앉다', '달리다'와 '뛰어오르 다'에서 차이가 높지 않음을 알 수 있다P>0.05).

각 조사구별 녹지손상도는 조사구 4 에서 1.31 로 가장 높았고, 조사구 3 이 0.97 , 조사구 1 이 0.91 , 조사구 2 가 0.70 의 순으로 나 타났다.

\section{3. 총 손상면적}

각 조사구에 있어서의 이용행태별 평균이용시간과 단위시간 당 활동량 등을 근거로 손상면적을 산출하였다. 손상면적 계산 에 있어 걷는 활동을 제외한 활동들의 경우에는, 각 활동에 따 른 녹지손상도를 '걷다'의 손상도로 환산한 값으로 산출하였다.

* 걷는 활동의 경우 손상면적 계산=평균이용시간×분당 평 균거리 $\div$ 보폭×평균 발면적

* 뛰는 활동의 경우 손상면적 계산=평균이용시간 $\times$ 분당 평 균거리 $\div$ 보폭×평균 접촉 면적×(손상도/보행 손상도)

* 기타 다른 활동의 경우 손상면적 계산=평균이용시간×분 당 평균횟수×평균 접촉 면적×(손상도/보행 손상도)

각 활동별 산출과정 및 결과는 표 8 과 같다. 조사구 4 에서 손 상면적이 가장 많고 조사구 3 에서 가장 적은 것으로 나타났다.

\section{4. 생태적 수용력의 계산 및 고찰}

조사구 $1,2,3,4$ 에서 1 일간 산출된 총 손상면적은 각각 $396.00 \mathrm{~m}^{2}, 420.57 \mathrm{~m}^{2}, 398.61 \mathrm{~m}^{2}, 1,392.90 \mathrm{~m}^{2}$ 이다. 각 총 손상면적 
은 녹지 수용력에 영향을 주는 손상횟수로 나누어 1 인당 면적 즉 이용밀도를 산출하고, 이를 다시 단위면적당 이용인수로 환 산하였다.

조사구 1 에서는 손상횟수 7 회/일을 기준으로 한 적정수용력 은 $56.57 \mathrm{~m}^{2}$ /인으로 산정되었고, 손상횟수 13 회/일을 기준으로 한 표준수용력은 $30.46 \mathrm{~m}^{2} /$ 인이며, 손상횟수 20 회/일을 기준으 로 한 한계수용력은 $19.80 \mathrm{~m}^{2} /$ 인으로 산정되었다. 이는 다시 적 정수용력 0.018 인 $/ \mathrm{m}^{2}$, 표준수용력 0.033 인 $/ \mathrm{m}^{2}$, 한계수용력 0.051 인 $/ \mathrm{m}^{2}$ 등으로 환산될 수 있다. 조사구 2 는 손상횟수 7 회/일을 기준으로 한 적정수용력은 $60.08 \mathrm{~m}^{2} /$ 인, 손상횟수 13 회/일을 기 준으로 한 표준수용력은 $32.35 \mathrm{~m}^{2} /$ 인, 손상횟수 20 회/일을 기준 으로 한 한계수용력은 $21.03 \mathrm{~m}^{2} /$ 인으로 산정되었다. 이는 다시 적정수용력 0.017 인 $/ \mathrm{m}^{2}$, 표준수용력 0.031 인 $/ \mathrm{m}^{2}$, 한계수용력 0.048 인 $/ \mathrm{m}^{2}$ 등으로 환산된다. 조사구 3 은 손상횟수 7 회 $/$ 일을 기준으로 한 적정수용력은 $56.94 \mathrm{~m}^{2} /$ 인, 손상횟수 13 회/일을 기 준으로 한 표준수용력은 $30.66 \mathrm{~m}^{2} /$ 인, 손상횟수 20 회/일을 기준 으로 한 한계수용력은 $19.93 \mathrm{~m}^{2} /$ 인으로 산정되었다. 이는 다시 적정수용력 0.018 인 $/ \mathrm{m}^{2}$, 표준수용력 0.033 인 $/ \mathrm{m}^{2}$, 한계수용력 0.050 인 $/ \mathrm{m}^{2}$ 등으로 환산된다. 조사구 4 는 손상횟수 7 회/일을 기준으로 한 적정수용력은 $198.99 \mathrm{~m}^{2} /$ 인, 손상횟수 13 회/일을 기준으로 한 표준수용력은 $107.15 \mathrm{~m}^{2} /$ 인, 손상횟수 20 회/일을 기준으로 한 한계수용력은 $69.65 \mathrm{~m}^{2} /$ 인으로 산정되었다. 이는 다시 적정수용력 0.005 인 $/ \mathrm{m}^{2}$, 표준수용력 0.009 인 $/ \mathrm{m}^{2}$, 한계수 용력 0.014 인 $/ \mathrm{m}^{2}$ 등으로 환산된다.

이러한 이용밀도 행태의 수용력은 실제 녹지공간에 그대로 적 용하여 각 수용력 수준별로 수용 이용인수를 추정할 수 있다. 1 일 표준수용력의 경우를 예로 들면 조사구 1 의 녹지면적 $2,300 \mathrm{~m}^{2}$ 는 75 인, 조사구 2 의 녹지면적 $15,000 \mathrm{~m}^{2}$ 는 463 인, 조사구 3 의 녹 지면적 $6,100 \mathrm{~m}^{2}$ 는 198 인, 조사구 4 의 녹지면적 $7,500 \mathrm{~m}^{2}$ 는 69 인 으로 추정된다. 또한 같은 방식으로 1 일 적정수용력은 각각 40

표 9. 각 조사구의 손상면적 및 생태적 수용력

\begin{tabular}{|c|c|c|c|c|}
\hline 조사구 & & 손상면적 $\left(\mathrm{m}^{2}\right)$ & 녹지총면적 $\left(\mathrm{m}^{2}\right)$ & 인수 \\
\hline \multirow{3}{*}{ 조사구 1} & 적정수용력 & \multirow{3}{*}{396.00} & \multirow{3}{*}{2,300} & 40 \\
\hline & 표준수용력 & & & 75 \\
\hline & 한계수용력 & & & 116 \\
\hline \multirow{3}{*}{ 조사구 2} & 적정수용력 & \multirow{3}{*}{420.57} & \multirow{3}{*}{15,000} & 249 \\
\hline & 표준수용력 & & & 463 \\
\hline & 한계수용력 & & & 713 \\
\hline \multirow{3}{*}{ 조사구 3} & 적정수용력 & \multirow{3}{*}{398.61} & \multirow{3}{*}{6,100} & 107 \\
\hline & 표준수용력 & & & 198 \\
\hline & 한계수용력 & & & 306 \\
\hline \multirow{3}{*}{ 조사구 4} & 적정수용력 & \multirow{3}{*}{$1,392.9$} & \multirow{3}{*}{7,500} & 37 \\
\hline & 표준수용력 & & & 69 \\
\hline & 한계수용력 & & & 107 \\
\hline
\end{tabular}

인, 249 인, 107 인, 37 인으로 추정되며, 1 일 한계수용력은 각각 116 인, 713 인, 306 인, 107 인으로 추정된다(표 9 참조).

이상의 결과를 종합하여 4 가지 조사구의 1 일 한계수용력은 비교해 보면, 조사구4의 한계수용력을 초과하는 이용인수가 이 용하고 있는 것으로 나타났다. 세계유산을 관리할 때 이러한 이용은 가급적 단기간에 끝나도록 조절하고, 그에 상응하는 회 복기간을 확보하는 등의 관리상의 배려가 요구된다.

\section{IV. 결론}

경주 동궁과 월지 관리의 기본 목표는 녹지의 질이 손상되지 않는 범위 내에서 탐방객들에게 양질의 경험을 제공하는 것이 다. 유적내 생태적 수용력 산정을 위한 이용행태 조사 및 연구 결과 다음과 같은 결론을 얻었다.

7 가지 이용행태에 따른 1 일 평균손상도는 '걷다' 활동이 2.15 로 가장 높았고, '멈추다' 2.10 , '일어서다' 0.83 , '앉다' 0.75 , '달 리다' 0.50 , '뛰어오르다' 0.45 , '눕다' 0.05 등의 순으로 나타났다.

7 가지 이용행태에 따른 4 개 조사구의 1 일 평균손상도 값은 각각 다른 값으로 나타났다. 조사구 1 의 경우 1 일 평균손상도 는 0.91로 나타냈으며, 조사구 2는 0.70 , 조사구 3은 0.97, 조사 구 4 는 1.31 로 나타냈다. 이 결과에 의하면 조사구 4 의 손상도 가 가장 높은 것으로 확인되었다.

이용행태에 따른 각 조사구별 평균 손상도를 통하여 경주 동 궁과 월지의 생태적 수용력을 명확하게 파악하였다. 조사구 1 , $2,3,4$ 의 1 일 적정수용력은 각각 40 인, 249 인, 107 인, 37 인으로 추정되며, 1 일 한계수용력은 각각 116 인, 713 인, 306 인, 107 인으 로 추정된다. 1 일 표준수용력은 각각 75 인, 463인, 198 인, 69인 으로 추정된다.

본 연구에서는 적정수용력을 비교해 보면, 조사구 4 에서 $198.99 \mathrm{~m}^{2} /$ 인으로 나타나, 다른 지구에서 보다, 훨씬 낮은 밀도기준으로 나타났음을 알 수 있다. 이는 조사구 4 의 잔디공간이 다른 잔디 공간에 비해 이용량이 훨씬 많기 때문이다. 그러나 이들 이용 량은 많은 이용인수 때문이라기보다는, 조사구 4 에서 잔디공간 의 평균이용시간이 다른 잔디공간의 경우보다 훨씬 길기 때문 이다.

이 연구는 경주 동궁과 월지의 생태적 수용력을 추정하기 위 하여 4 구역별 녹지를 위주로 연구하였다. 경주 동궁과 월지의 생태적 수용력과 더불어 시설수용력, 사회적수용력 등을 추가 하여 비교분석하지 못한 점은 본 연구의 한계라 할 수 있다. 미 흡한 점은 후속연구를 통해 보완될 수 있을 것으로 생각한다.

\section{인용문헌}

1. 국립공원관리공단(2007) 국립공원 수용력 관리시스템 연구. 국립공원관 리공단. 
2. 김선희(2005) 관광지의 적정 수용력 산정과 관리 방안 연구: 광릉지역 을 사례로. 대한지리학회지 40(3): 321-334

3. 김창수, 김의근(1995) 관광지의 적정수용력 측정에 관한 연구. Journal of Tourism Systems and Quality Management 1(2, 3, 4): 41-58.

4. 박지나, 이승곤, 이후석(2009) 혼잡지각에 따른 방문객 만족과 자연휴양 시설의 사회심리적 수용력 추정에 관한 연구. 관광학연구 33(6): 93-110.

5. 신원섭, 권헌교, 한상열(2007) 국립공원 탐방집중도 분석 및 사회 - 심리 적 수용력 평가. 한국산림휴양학회지 11(2): 43-50.

6. 엄붕훈(1992) 공원녹지공간의「레크레이션」수용력에 관한 연구(II) 녹지공간의 이용행태 분석 및 생태적 수용력의 추정. 한국조경학회지 20(2): 1-17.
7. 오규식, 정연우, 이동근, 이왕기(2002) 지속가능한 도시환경을 달성하기 위한 통합적 도시 수용력 평가체계 수립. 국토계획 37(5): 7-26

8. 조현길(1989) 산악형 국립공원 야영장의 수용력 산정에 관한 연구. 서울 대 환경대학원 석사학위논문

9. 近藤三雄(1980) 芝生地の收容力に關する基礎的研究(III)：利用者の行動 なちびに芝生地の損傷度に基つ”く收容力の算定についそ，造園雜志 43(4): $3-11$.

10. Canestrelli, E. and P. Costa(1991) Tourist carrying capacity: A fuzzy approach. Annals of Tourism Research 18: 295-311.

11. Godschalk, D. R. and F. H. Parker(1975) Carrying capacity: A key to environmental planning? Journal of Soil and Water Conservation 30(4): 160-165.

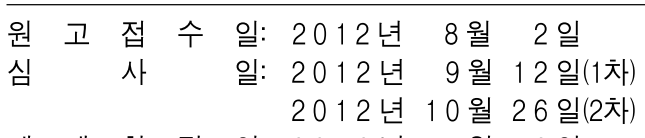

게 재 확 정 일: 2012 년 11 월 12 일

4 인 익 명 심 사 필 